\title{
Thermo economic analysis for the optimal conceptual design of biomass gasification energy conversion systems
}

\author{
David Brown $^{\text {a }}$, Martin Gassner ${ }^{\mathrm{b}}$, Tetsuo Fuchino ${ }^{\mathrm{a}}$, François Maréchal ${ }^{\mathrm{b}}$
}

a. Tokyo Institute of Technology, S1-18, 2-12-1 Ookayama, Meguro ward, Tokyo, 152-8550 Japan; Phone / Fax: +81357342474

Email: brown@chemeng.titech.ac.jp \& fuchino@chemeng.titech.ac.jp

b. Ecole Polytechnique Fédérale de Lausanne, LENI-ISE-STI-EPFL, Station 9, CH-1015, Lausanne, Switzerland ; Phone: +41 21693 3516; Fax: +41 216933502

Email: martin.gassner@epfl.ch \& francois.marechal@epfl.ch

\begin{abstract}
This study addresses the thermo economic assessment of a mid-scale ( $20 \mathrm{MW}_{\text {th,wood }}$ ) wood gasification, gas cleaning and energy conversion process, with particular attention given to electricity generation costs and tar control. Product distributions were estimated with a parametric stoichiometric equilibrium model calibrated using atmospheric air gasification data. A multi-objective optimisation problem was defined for a superstructure of alternative energy flow diagrams for each processing step. The trade-off between total investment costs and the exergy efficiency of electricity production was obtained, and analysed to identify operating conditions that minimise tar formation to prevent equipment fouling. The use of air, oxygen or steam fluidised bed gasifiers, closed coupled to an internal combustion engine combined cycle (ICE-CC) requiring cold gas cleaning, or gas turbine combined cycle (GT$\mathrm{CC}$ ) requiring hot gas cleaning have been considered. The operating conditions that maximise ICE-CC efficiency with cold gas cleaning (low pressure and high temperatures) also favour minimal tar formation. For GT-CC tar concentrations are higher, but this should not be of concern provided that hot gas cleaning can effectively prevent tar condensation. The trade-off appears to be optimal for steam gasification, with minimal specific costs of $2.1 € / \mathrm{We}$ for GT$\mathrm{CC}$, and $2.7 € / \mathrm{We}$ for ICE-CC. However, further calibration of the reaction model is still needed to properly assess product formation for other oxidants than air, and to properly take account of the impact of pressure on product distributions. For air gasification, the minimal specific cost of GT-CC is $2.5 € / \mathrm{We}$, and that of ICE-CC $3.1 € / \mathrm{We}$.
\end{abstract}

\section{$\underline{\text { 1. Introduction }}$}

In the past decades, significant efforts have been directed towards the development of biomass gasifiers to replace traditional combustion systems [1-3]. Indeed, it is possible to increase power production with biomass based integrated gasification combined-cycle (IGCC). One of the incentives of IGCC is that power generation from biomass is limited to modest production scales that are a disincentive to high efficiency steam cycles operating at higher pressures, because the low energy density of feedstocks incurs high collection costs [4]. Furthermore, as an alternative to onsite power generation, gasification processes may also serve the purpose of producing synthetic fuels such as methane (e.g. [5-6]). However, biomass gasification projects are hindered by the difficulty of quantifying, under different operating conditions, the distribution of gas species, in particular condensable organic compounds known as tar, and of char components. Tar deposits are an economical bottleneck to gasification, as they induce frequent equipment shutdowns for maintenance and repair, sometimes even the need for duplicate equipments for gas cleaning, to avoid complete process 
shutdowns. The design problem is thus one of identifying a combination of gasification, gas cleaning, and energy conversion technologies that favour minimal contaminant formation, together with a high net conversion efficiency. Modelling tar formation generally requires experimental measurements, which are difficult to retrieve, due to the complexity and absence of unified standards for sampling methods [7-8]. The difficulty of properly estimating product distributions has an impact on the identification of promising flowsheet design alternatives, hence on the overall efficiency and economics of gasification.

In short, the design of a biomass based energy conversion system is a typical example of a preliminary conceptual chemical process flowsheet design problem, with several choices of reaction, separation, energy conversion, and heat recovery units. In the present study, we have conducted a thermo economic assessment of a small scale electricity production system, with a particular emphasis on the influence of process operating conditions on tar formation and the costs of electricity generation. This study was undertaken by formulating a flowsheet optimisation superstructure.

Following a review of producer gas cleaning technologies and of the equipment requirements for biomass based electricity generation, the development of the gasification process optimisation superstructure will be presented and its application illustrated by comparing air, oxygen, and steam fluidised bed gasifiers, as well as hot gas cleaning and cold gas cleaning processes. The superstructure was formulated with process energy flow diagram alternatives [cf. 9-11], and the heat exchanger network structure resolved by a sub-problem that uses the heat cascade concept [12]. A stoichiometric equilibrium model with reaction temperature difference parameter regressions has been implemented to account for the nonequilibrium distribution of gasification products [13].

\section{$\underline{\text { 2. Producer gas contaminants and gas cleaning technologies }}$}

\subsection{Tar}

\subsubsection{Definition of biomass tar}

Tar is an operational parameter that designates the condensable organic components of producer gas [7]. There is no unique definition of the term, but there is a broadening consensus in defining biomass tar as "organic contaminants with a molecular weight larger that benzene" $(78 \mathrm{~kg} / \mathrm{kmol})$ [14-15]. Biomass tar has been classified in three categories according to the severity, i.e. reaction time and temperature, of pyrolysis conditions $[7 ; 16-$ 17]. Primary products that form at the lowest temperatures and the shortest reaction times are oxygenated compounds analogous to plant materials, secondary and tertiary products that form from subsequent gas phase reactions, become progressively aromatic [16-17]. Primary tar is mostly destroyed before the appearance of tertiary species [16]. Tar concentrations can vary widely according to gasifier types and operating conditions. For fluidised bed gasifiers they can range from $10-50000 \mathrm{mg} / \mathrm{Nm}^{3}$ [17]. A simple illustration of the classification is summarised in Table 1, with typical temperature ranges at which different types of tar appear.

Tar can be physically removed, or chemically converted into lighter gas species by thermal or catalytic reactions. Gas cleaning processes are also classified as primary measures for tar control in the gasifier, as opposed to secondary measures downstream the gasifier.

Table 1. Simplified classification of biomass tar according to formation temperature

\begin{tabular}{llll}
\hline Category & Primary & Secondary & Tertiary \\
\hline Range $\left({ }^{\circ} \mathrm{C}\right)$ & $400-600$ & $600-800$ & $800-1000$ \\
Species & acids, phenols, ketones, & phenols, heterocyclic ethers & $\begin{array}{l}\text { non substituted } \\
\text { guaialcols, furans, furfurals }\end{array}$ \\
& monoaromatic hydrocarbons & polyaromatic hydrocarbons \\
\hline
\end{tabular}




\subsubsection{Gasifier operating conditions for tar control}

The selection of a proper gasification technology and operational parameters are considered as primary measures for tar control [15]. For instance, fixed bed co-current gasifiers and circulating fluidised beds produce less tar than fixed bed counter-current gasifiers [7; 18]. Measures of interest for fluidised bed gasification include,

- injecting secondary air or steam to the freeboard (above bed height). In a ratio of up to $10 \%$ of the inlet air, secondary air can decrease tar concentrations by a factor of scale [19], but this reduces producer gas heating value. Steam or oxygen can accelerate primary tar conversion and inhibit PAH formation in the presence of catalysts, and steam injection may regenerate nickel catalysts poisoned by sulfur [20].

- maintaining an high freeboard temperature [21].

- separating pyrolysis and reduction zones. Namely, indirectly heated gasification by steam or $\mathrm{CO}_{2}$ reforming can significantly decrease tar formation [15].

- recycling char to the gasifier as a bed material [14-15].

\subsubsection{Physical tar removal processes}

Physical tar separation involves extraction units, typically bag filters, wet scrubbers. They are efficient and require little maintenance, but entail important filter disposal and effluent treatment expenses [7]. As the oxygenated primary and secondary tars are water soluble and detrimental (e.g. phenol) to effluent treatment [22-23], the use of scrubbers operating above the water condensation point with different solvents or solid adsorbent particles -enabling tar recycling to the gasifier- has also been investigated [23-24]. Wet electrostatic precipitators are also efficient for tar control, but due to their high capital costs they are typically not used for biomass producer gas cleaning [14]. Packed bed filtering using inert (e.g. sand or ceramic spheres) or reactive packing materials (e.g. char or sawdust) can also efficiently remove tar. This type of technology is relatively inexpensive, thus attractive for small scale projects (e.g. less than $1 \mathrm{MW}$ ), but bed cleaning can be hazardous and impractical, and the accumulation of contaminants create operability problems for larger scale processes $[14 ; 18]$.

Physical separation processes may potentially reduce energy conversion efficiency. Of particular concern are wet scrubbers and wet electrostatic precipitators which imply quenching the producer gas to $35-60^{\circ} \mathrm{C}$. Packed sawdust bed filtering also requires low operation temperatures. Bag filters can be sufficiently resistant for gas cleaning at up to $350^{\circ} \mathrm{C}$. Other separation processes can be operated at even higher temperatures.

\subsubsection{Chemical tar conversion processes}

Chemically destroying tar can alleviate waste treatment issues associated to physical separation processes, and can also prevent reducing the heating value of producer gas.

Thermal conversion processes involve raising the producer gas temperature typically above $1000^{\circ} \mathrm{C}$, to crack tars into lighter species. Morf et al [17] observed that $\mathrm{CO}$ and $\mathrm{CH}_{4}$ concentrations increase linearly between $700^{\circ} \mathrm{C}$ and $1000^{\circ} \mathrm{C}$, whereas $\mathrm{H}_{2}$ concentration increase exponentially, equalling $\mathrm{CO}$ concentration at $1000^{\circ} \mathrm{C}$. Thermal tar destruction increases the yields of PAH and soot [16-17]. Sooting incurs a reduction in producer gas carbon content, hence in heating value. In addition, thermal tar cracking reactors operate at high temperatures, thus have to be constructed with expensive materials that resist heat. Lastly, thermal tar conversion is an energy penalty to processes utilising fluidised bed gasifiers typically operated below $1000^{\circ} \mathrm{C}$ [7].

Catalytic conversion processes can be operated at lower operating temperatures hence eliminating the heating and material requirements of thermal processes. Furthermore, catalysts enhance the conversion of tar to producer gases, and prevent excessive sooting. Tar 
conversion catalysts are either metal based -often nickel [25-26], or mineral such as olivine [27], limestone [28], and dolomite [20-21]. In situ tar conversion with a metal catalyst is uneconomic because it is rapidly deactivated, either due to $\mathrm{H}_{2} \mathrm{~S}$ deactivation or dust plugging. If $\mathrm{H}_{2} \mathrm{~S}$ concentrations exceed $200 \mathrm{ppm}$, the operating temperature must be maintained above $850^{\circ} \mathrm{C}-900^{\circ} \mathrm{C}$ to avoid nickel catalyst deactivation [25-26]. However, at high operating temperatures, bed sintering may occur if the feedstock has a high alkali concentration. Because metallic catalysts are more expensive, more rapidly and easily deactivated, but also more efficient than mineral catalysts, it is generally recommended to make use of reactors in series, i.e. first a mineral catalyst (a so-called guard bed) to convert the bulk of tar, and secondly a metal catalyst for further cleaning $[15 ; 20]$. Contrarily to metal based catalysts, it is reasonable to consider in situ use of certain mineral catalysts, e.g. for dolomite, in situ and downstream use were observed to be equally efficient [29]. Still, care must be taken to avoid bed material attrition and elutriation. In this respect, olivine is said to be more resistant than dolomite [15]. Lastly, loading a nickel based catalyst in the pores of particle filters has been suggested as a means of further process intensification [26;30].

\subsection{Other gas contaminants}

Other gas contaminants that, depending on feedstocks and operating conditions, may need to be removed or chemically converted include organic dust particles, fly ash including alkali vapours, and light nitrogen and sulfur gases.

\subsubsection{Nitrogen and sulfur gases}

Nitrogen and sulfur gases are precursors to acid rain and photochemical smog. The low temperature and oxygen deficient conditions of fluidised bed biomass gasification do not favour NOx formation, but predominantly the release of gaseous nitrogen as ammonia $\left(\mathrm{NH}_{3}\right)$. $\mathrm{NH}_{3}$ is however, a NOx precursor that ultimately forms from producer gas combustion (i.e. in a furnace, engine or gas turbine). At high combustion temperatures, thermal NOx can form simply from the addition of $\mathrm{N}_{2}$ and $\mathrm{O}_{2}$, but 75 to $95 \%$ of $\mathrm{NOx}$ emissions originate from fuelbound nitrogen [31]. NOx control can be done through fume recirculation and post combustion, and also through the catalytic or thermal conversion of $\mathbf{N H}_{3}$ (or urea) and $\mathrm{NOx}$ to $\mathrm{N}_{2}$ and water [32]. The lower temperatures typical of fluidised bed gasification also increase nitrous oxide $\left(\mathrm{N}_{2} \mathrm{O}\right)$ emissions a green house gas 270 to 320 times stronger than $\mathrm{CO}_{2}$. $\mathbf{N}_{2} \mathbf{O}$ emissions can be decreased by the addition of secondary fuel downstream the gasifier [33]. Therefore, fuel reburning and fume recirculation appear as more manageable means of combining $\mathrm{NOx}$ and $\mathrm{N}_{2} \mathrm{O}$ control, than temperature control for which there is little possible compromise. When cold gas cleaning is considered, acid gases such as $\mathrm{NH}_{3}$ but also $\mathrm{H}_{2} \mathrm{~S}$ can also be removed by wet scrubbers. The sulfur content of biomass is typically considerably lower than that of coal, and sulfur gas removal is not always a necessity [4; 14]. The notable exception is black liquor in which sulfur is a recoverable pulping chemical.

\subsubsection{Particulates (fly ash and dust particles)}

Particulates are fine dust particles of organic and inorganic nature entrained out of the gasifier by product gases, and that can cause equipment corrosion and clogging. Fluidized bed gasifiers have a greater production capacity and feedstock flexibility than fixed bed gasifiers, however their particulate emissions are considerably greater. Particulates include organic dust particles and incombustible particles termed fly ash.

Particulates can be removed or partly recycled to the gasifier by physical processes, many of which, as has been mentioned previously, can efficiently contribute to tar control. It is, however, preferable to perform particulate removal at high temperatures and remove tar 
separately, because tar condensation on particulate surfaces can aggravate gas cleaning equipment plugging and fouling problems [14]. Cyclones are often an integral part of fluidised beds reactor designs, allow recycling large particulates and bed material to the gasifier (thereby increasing carbon conversion efficiency) and can be operated at gasification temperatures, but are ineffective at removing particles of sub-micron dimensions. Particulates as small as 0.5 microns, can efficiently be removed by ceramic candle or sintered metal filters which can be operated close to gasifier temperatures. Filters are still relatively novel and costly equipments $[4 ; 24]$, and are susceptible of breakdown due to mechanical fatigue [34]. Wet scrubbers can also handle particles of similar sizes [14; 18]. Finer particulates can be removed by bag filters or dry electrostatic filters operating at temperatures of up to $500^{\circ} \mathrm{C}$ [14- 18]. Packed bed filters can also be used for particulate removal. As previously stated, however, electrostatic filters (due to high investment costs) and packed bed filters (due to waste disposal and operability issues), have limited applications for biomass producer gas cleaning.

Due to the importance of their alkali content (potassium and sodium), certain components of biomass ashes are dense, sticky, and reactive. Alkalis combine with chlorine to form low melting point eutectics that are entrained in gas as aerosols. Thus, chlorine concentration becomes an indicator of the amount of alkali vaporised during fuel decomposition [35]. Alkali chlorides can condense and induce corrosion on metal surfaces in the cooler zones of the gasifier such as superheater tubes, or other equipments, e.g. the blades of gas turbines. Alkali chlorides can also cause bed agglomeration in fluidised reactors. Sulfatation and the addition of alumino silicates can prevent alkali chloride formation [3637]. Alkali chlorides can be removed by physical separation processes downstream the gasifier. In demonstration and industrial processes, bag filters or scrubbers are normally used for separating alkali contaminants, and the producer gas temperature in upstream equipments is maintained below the alkali chloride eutectic fusion point $\left(450-600^{\circ} \mathrm{C}\right)$ to avoid corrosion problems. Experimental results have also indicated that alkali chlorides can be removed at $650-725^{\circ} \mathrm{C}$ with ceramic filters and a packed beds with bauxite sorbants [38]. Simply deashing the feedstock, e.g. by leaching and dewatering prior to drying and gasification is also effective for alkali control [35; 39]. Alkali (especially potassium) concentrations are higher in younger plant tissues, therefore corrosion problems are especially of concern for annual feedstocks such as straw (or also leaves, shells, hulls, pits, etc.); perennial feedstocks like the mature stem of wood have low alkali contents [35].

\subsection{Concluding remarks on gas cleaning}

The design of gas cleaning systems is not a trivial matter, due to the presence of a variety of contaminants. Gas cleaning equipment capital investment, maintenance and operation can be noticeably costly. This highlights the importance of selecting proper primary measures, including gasifier operating parameters, to minimise the formation of tar and other contaminants prior to considering secondary gas cleaning options. In addition, an optimal integration of downstream gas cleaning equipments is desirable to improve the overall process energy conversion efficiency and reduce operating costs. Cold gas cleaning is preferable when the producer gas has to be cooled, e.g. for further processing, or to be transported for offsite consumption. Furthermore, if not removed by condensation, pyrolytic water decreases the heating value of the gas. When however, a prime mover is close-coupled to the gasifier, hot gas cleaning has the advantage of eliminating the need for extensive tar control. 


\section{$\underline{\text { 3. Electricity production scale and equipment requirements }}$}

Due to feedstock collection and transportation costs, electricity production from biomass is typically limited to less than $100 \mathrm{MWe}$. Even when biomass is a by-product of an industrial activity, e.g. in pulp and paper processes [40-41], the electricity production potential remains of the same order. As shown in Table 2. where examples of energy conversion processes are listed, this limitation on scale has important repercussions on gasifier design considerations. State of the art coal IGCC plants utilise expensive oxygen blown entrained flow gasifiers, built for larger scale operations typically exceeding $250 \mathrm{MWe}$, and operated at temperatures of $1200^{\circ}-2000^{\circ} \mathrm{C}$ and pressures exceeding 20 bar. For the 2 to $32 \mathrm{MWe}$ range covered in Table 2, biomass gasifiers are air or steam blown fluidised beds, operated below $1000^{\circ} \mathrm{C}$, often in atmospheric conditions. Fixed bed gasifiers are suitable for smaller production scales of less than $1 \mathrm{MWe}$. Beyond this uniform reaction temperatures can be difficult to achieve due to uneven gas flows and the absence of mixing mechanisms [14]. For a production of less than $10 \mathrm{MWe}$, the specific capital costs of biomass IGCC can be of the order of 2000-4000 $€ / \mathrm{kWe}$ (e.g. [42]), and the cogeneration of steam (e.g. for district heating applications) becomes an important economic factor. For the $32 \mathrm{MWe}$ scale [43], specific capital costs could reportedly be lower than $2000-1200 € / \mathrm{kWe}$. Comparatively, the specific costs of coal IGCC can range from less than $1000 € / \mathrm{kWe}$ to $1500 € / \mathrm{kWe}$ [44], but the upper limit also accounts for the cost of $\mathrm{CO}_{2}$ sequestration.

Table 2. Examples of demonstration gasification plants

\begin{tabular}{llllll}
\hline Reference & $\begin{array}{l}\text { Hofbauer } \text { et al. } \\
{[45]}\end{array}$ & Stahl et al. [34] & $\begin{array}{l}\text { Pitcher } \text { et al. } \\
{[46]}\end{array}$ & $\begin{array}{l}\text { Waldheim \& } \\
\text { Carpentieri [43] }\end{array}$ & $\begin{array}{l}\text { Brun \& Jones } \\
{[44]}\end{array}$ \\
\hline Feedstock & Wood & Bio (misc.) & Wood & Wood & Coal \\
Oxidant & Steam & Air & Air & Air & Oxygen \\
Power output & $2 \mathrm{MWe}$ & $6 \mathrm{MWe}$ & $8 \mathrm{MWe}$ & $32 \mathrm{MWe}$ & $800 \mathrm{MWe}$ \\
District heating & $4.5 \mathrm{MWth}$ & $9 \mathrm{MWth}$ & - & - & - \\
Efficiency* & $25 \%$ & $33 \%$ & $29 \%$ & $40 \%$ & $43 \%$ \\
Gasifier & Atmospheric & Pressurised & Atmospheric & Atmospheric & Pressurised \\
Gas cleaning & Cold & Hot & Cold & Cold & Cold \\
Cycle & ICE & GT-CC & GT-CC & GT-CC & GT-CC \\
\hline
\end{tabular}

Notes: * electricity conversion efficiency

The remainder of this section will relate to mechanical power sources for electricity production. Attention will also be given as to how production scale and the particularities of biomass feedstocks can affect cycle efficiencies and the selection of prime movers.

\subsection{Boilers and Rankine cycles}

One of the incentives of gasification, is avoiding fire side corrosion otherwise induced by fuel alkali deposits with direct high temperature biomass combustion in boiler furnaces [35]. More importantly, boiler efficiency is also limited by the scale dependency of boiler costs to steam cycle power output. To minimise specific costs at a production scale of less than 100 MWe, biomass boilers reportedly operate at pressures of less than 60 bar with maximum reheat temperatures of the order of $480^{\circ} \mathrm{C}$, limiting electricity conversion efficiencies to $15-25$ $\%$ [4]. Therefore due to economic and equipment fouling concerns, gasification combined cycle (CC) with heat recuperation by steam generation appears advantageous for electricity production. Other than steam cycles, organic Rankine cycles can also be of interest for small scale CC [47]. 


\subsection{Topping cycles}

As is suggested in Table 2., internal combustion engine combined cycle (hereafter ICE$\mathrm{CC}$ ) or a gas turbine combined cycle (hereafter GT-CC) can realistically be considered for biomass based power generation. Feed gas quality requirements for these prime movers are as follows [7; 18],

- ICE-CC: tar concentrations should be $<100 \mathrm{mg} / \mathrm{Nm}^{3}$, and particulates $<50 \mathrm{mg} / \mathrm{Nm}^{3}$,

- GT-CC: tar concentrations should be $<5 \mathrm{mg} / \mathrm{Nm}^{3}$, and particulates $<30 \mathrm{mg} / \mathrm{Nm}^{3}$.

\subsubsection{Gas turbines}

Although also subject to economies of scale, the investment costs of gas-turbine systems can be advantageous both for large and small scale electricity production. For instance, aeroderivative turbines are smaller than industrial turbines and have higher combined cycle efficiency at modest loads, and can therefore be suitable for small scale electricity production [4]. Furthermore, hot gas cleaning can be considered for GT-CC. Indeed, considering the lower tolerance of gas turbines to tar, and the pressure losses incurred in scrubbers, cold gas cleaning is not necessarily attractive for GT-CC. Conversely, with hot gas cleaning, it is possible by close coupling a pressurised gasifier and a gas turbine, to avoid having to recompress the producer gas and to maintain the temperature at the inlet of the burner high enough to prevent tar condensation, thereby increasing energy conversion efficiency and potentially reducing investment and maintenance costs [4; 19; 42].

\subsubsection{Internal combustion engines}

Internal combustion engines (ICE) need to be fuelled with cold gas, therefore wet gas scrubbers are generally used to clean producer gas for this type of prime mover [22]. Hence the disposal of tar contaminated effluents must be taken into account. Compared to gas turbines, ICE have been said to be more efficient and can be economically more attractive for small scale electricity production up to a break-even point of about 5-6 MWe above which the specific costs of GT-CC are said to be lower [22; 48]. Producer gas can partially replace oil in compression ignition (diesel) engines, or be used on its own in spark ignition (gasoline) engines. Liquid fuel replacements of up to $85 \%$ are attainable in so called dual fuel (or gas diesel) engines which are said to have higher efficiencies than spark engines. But it is possible to increase the efficiency of producer gas fuelled spark engines by operating them at high compression ratios [49].

\section{Thermo-economic optimisation problem formulation}

The developed approach for conceptual biomass gasification process design will be explained and illustrated in the following sections. A modified equilibrium model was derived from experimental data to account for the formation of gasification products under changing operating conditions. This model has been integrated to a process simulation superstructure for which the selection of processing units and operating conditions was investigated by considering gas cleaning requirements and the insertion of energy conversion systems. Process equipment costs and sizing parameters were derived from the gasifier types and operating conditions. The design problem was solved with a multi-objective optimiser.

\subsection{Gasification reaction modelling}

The gasification reactions have been modelled with temperature difference parameters for chemical equilibrium calculations, i.e. mimetic estimators of the non-equilibrium product 
distribution of biomass gasification [13]. The gasification model was developed with air gasification data from a pilot circulating fluidised bed reactor operated at atmospheric pressure [50]. Firstly, light gas specie, total tar and char concentration were verified by mass balance reconciliation. Secondly, the distribution of a subset of tar species was determined from the quantity and elemental composition of the total tars by non-stoichiometric equilibrium calculations. Finally a complete stoichiometry was written for the reaction system, and fitted to the calculated product distribution by letting reaction equilibrium temperatures vary from the measured gasification temperature. A multivariate regression relates producer gas tar and char distribution variations to operating conditions and fuel compositions [13]. This model enables evaluating the effect of operating conditions on gas, tar and char formation. Particulate formation was not modelled here, although particulate removal equipment costs were included in the economic analysis.

The operational variables of the database are feedstock compositions including moisture content, air equivalence ratios, and reaction temperatures. Reaction temperature difference parameters were calculated according to product distributions under changing operating conditions and correlated to these variables. The thermodynamic properties of biomass were obtained from atomic group contributions. Char was assumed to be solid graphite (C). The light gas species considered were $\left\{\mathrm{O}_{2}, \mathrm{H}_{2} \mathrm{O}, \mathrm{H}_{2}, \mathrm{CO}_{2}, \mathrm{CO}, \mathrm{CH}_{4}, \mathrm{~N}_{2}, \mathrm{NH}_{3}\right\}$ and $\mathrm{C}_{2} \mathrm{H}_{4}$ representing all remaining light hydrocarbon gases. Four model tar compounds were kept for flowsheet calculations: furfural, phenol, naphthalene, and pyridine. The stoichiometry was generated from the following master equation,

$$
\mathrm{C}_{\mathrm{n}} \mathrm{H}_{\mathrm{m}} \mathrm{O}_{\mathrm{p}} \mathrm{N}_{\mathrm{q}}+(\mathrm{n}-\mathrm{p}) \mathrm{CO}_{2} \longleftrightarrow(2 \mathrm{n}-\mathrm{p}) \mathrm{CO}+\left(\frac{\mathrm{m}}{2}-\frac{3}{2} \mathrm{q}\right) \mathrm{H}_{2}+\mathrm{qNH}_{3}
$$

where the formula $\mathrm{C}_{\mathrm{n}} \mathrm{H}_{\mathrm{m}} \mathrm{O}_{\mathrm{p}} \mathrm{N}_{\mathrm{q}}$ was successively replaced by the chemical species other than those already in Eq.(1). However, it is not necessary to find equilibrium temperature parameter regressions for $\mathrm{O}_{2}$ and the biomass pseudo-specie as total conversion can be assumed for these components.

\subsection{Flowsheet optimisation problem formulation}

\subsubsection{Process superstructure modelling methodology}

An optimisation superstructure has been built consistently with the procedure described in Godat and Maréchal [9], Maréchal et al. [10], and Bolliger et al. [11]. Flowsheets and economic models were developed for various unit operations and processing steps. The flowsheets were simulated as energy-flow models of wood drying, gasification, gas cleaning and energy conversion processes, using the Vali 4 software [51]. An energy flow model is a representation in which heat exchanger networks (HEN) are not defined, but only physical and chemical transformations and corresponding energy requirements are computed. This enables determining the optimal HEN and utility system in a separate energy-integration model. The integration of the HEN and steam network was optimised in regard to operating costs with a mixed integer linear programming sub-problem that makes use of the heat cascade concept [12]. Separate energy-flow and energy-integration models enable evaluating a greater number of process topologies, and how changes in operating conditions affect the optimal HEN and utility system configuration. Consequently, this avoids generating suboptimal solutions that prematurely constrain process topologies.

\subsubsection{Objective functions}

The first objective is the exergy efficiency of the electricity generation, formulated as, 
$\eta=\frac{w_{e}^{-}-\sum w_{i}^{+}}{\Delta k_{\text {wood }}^{0} \dot{m}_{\text {wood }}}$

where $w_{e}^{-}$is the electricity generated, $w_{i}^{+}$the power consumption of each process equipment, and $\dot{m}_{\text {wood }}$ the dry ash free (daf) mass flow rate and $\Delta k_{\text {wood }}^{0}$ the specific chemical exergy of wood calculated with the method of Szargut and Styrylska [52]. Also, we considered that no fuel other than wood could be imported to the process, nor waste heat exported from the process. The properties of wood specified in the model (an average value for a bend of soft wood and hard wood species) are given in Table 3.

Table 3. Composition and fuel properties of wood in gasification model

\begin{tabular}{llllllll}
\hline $\mathrm{C}$ & $\mathrm{H}$ & $\mathrm{O}$ & $\mathrm{N}$ & Moisture & $\mathrm{HHV}$ & $\mathrm{LHV}$ & $\Delta k_{\text {wood }}^{0}$ \\
{$[\% d a f]$} & {$[\% d a f]$} & {$[\% d a f]$} & {$[\% d a f]$} & {$[\% a f]$} & {$[\mathrm{MJ} / \mathrm{kg}]$} & {$[\mathrm{MJ} / \mathrm{kg}]$} & {$[\mathrm{MJ} / \mathrm{kg}]$} \\
\hline 51.09 & 5.75 & 42.97 & 0.19 & 50 & 19.6 & 16.2 & 20.9 \\
\hline
\end{tabular}

Notes. \% weight percentages; daf: dry ash free; af: ash free. HHV, LHV, and $\Delta k_{\text {wood }}^{0}$ are on dry basis but considering for the LHV the requirements for $50 \%$ moisture evaporation.

The second objective is the total grass roots costs $\mathrm{C}_{\mathrm{GR}}$, i.e. the total investment cost for a new production site as described in Turton et al. [53],

$C_{G R}=\left(1+\alpha_{1}\right) \sum C_{B M_{-} a c}+\alpha_{2} \sum C_{B M_{-} b c}$

where $C_{B M_{-} b c}$ is the bare module equipment costs at base case conditions (i.e. ambient operating pressure and carbon steel construction), and $C_{B M_{-} a c}$ the equipment costs considering actual operating conditions and construction materials. It is assumed that contingency and construction fees amount to $\alpha_{1}=18 \%$ of the total actual equipment costs, and that the cost for auxiliary facilities, site development and buildings amounts to $\alpha_{2}=35 \%$ of the total bare module costs at base case conditions. Equipment costs essentially depend on production scales and construction materials. However thermodynamic variables (e.g. temperature, pressure, and volumetric flow) rather than equipment capacities have been considered as decision variables in the flowsheet optimisation problem formulation.

\subsubsection{Optimiser}

A queuing multiple objective optimisation evolutionary algorithm (MOO-LENI [54]) with a non-dominated ranking scheme [55] was used to find the trade-off between both objective functions. The benefit of the stochastic algorithm is to prevent constraining the solution population to local minima that may arise due to the non-linear and non-convex nature of the design problem. However, there can be no explicit indication of convergence. It is assumed that the optimal trade-off, or the Pareto optimal frontier is reached when there are no new non dominated solutions after a certain number of iterations. For conceptual process design, the advantage of a multiple objective formulation is to generate a greater variety of feasible process configurations than with a single objective. In addition MOO-LENI uses clustering algorithms to generate solution groups around local optima. With MOO-LENI it is possible in theory to follow any number of objectives. When there are more than two objectives, however, the interpretation of results can be complicated.

\subsection{Optimisation cases studies}

\subsubsection{Flowsheet design alternatives}

The focus of this study is a $20 \mathrm{MW}_{\text {th,wood }}$ installation, i.e. $8 \mathrm{MWe}$ when considering an electricity conversion efficiency of the order of $40 \%$. As previously mentioned, this is a 
production scale favouring fluidised bed gasification. Six alternatives have been included in the optimisation superstructure. Each scenario combines either an air, steam, or oxygen gasifier, with either a cold gas cleaning process combined with a spark ignition ICE-CC, or a hot gas cleaning process combined with a GT-CC. These scenarios were inspired from two demonstration plant gasifier concepts: indirectly heated fast internally circulating fluidised bed (FICFB) steam gasification, as described in Hofbauer et al. [45] and Rauch et al. [56], or a directly heated oxygen blown CFB for air or oxygen gasification, as described in Stahl et al., [34]. In the actual demonstration plants, the FICFB [45; 56] was designed to operate in atmospheric conditions, and the CFB [34] as a pressurised system. Adjustments were made to the cost functions in order to account for the impact of pressure and volumetric flow variations, and extra compression costs. For lack of available data, the reaction model calibrated with atmospheric air gasification measurements was also used for modelling steam and oxygen gasification scenarios, also assuming that both gasifiers could be adapted to operate either in atmospheric or pressurised conditions. These assumptions became of interest for assessing the sensitivity of the equilibrium model with regard to pressure and the concentration of inert species in gas phase reactions.

Process flowsheet alternatives are shown in Figs. $1 \& 2$ in a block flow representation of energy flow diagrams. Wood, assumed to enter the process at $50 \%$ moisture content, is air dried prior to gasification. Oxidant gas compression is optional at the inlet of the gasifier. For oxygen gasification, an ASU using ceramic ion transfer membranes (ITM) was considered. ITM are typically operated at $800-900^{\circ} \mathrm{C}$ and a mechanical power consumption of approximately $150 \mathrm{kWh} /$ ton- $\mathrm{O}_{2}$ [57]. Other ASU technologies include cryogenic separation and pressure swing absorption, but in a preliminary analysis ITM appeared as the most economical option [6]. Unlike cryogenic

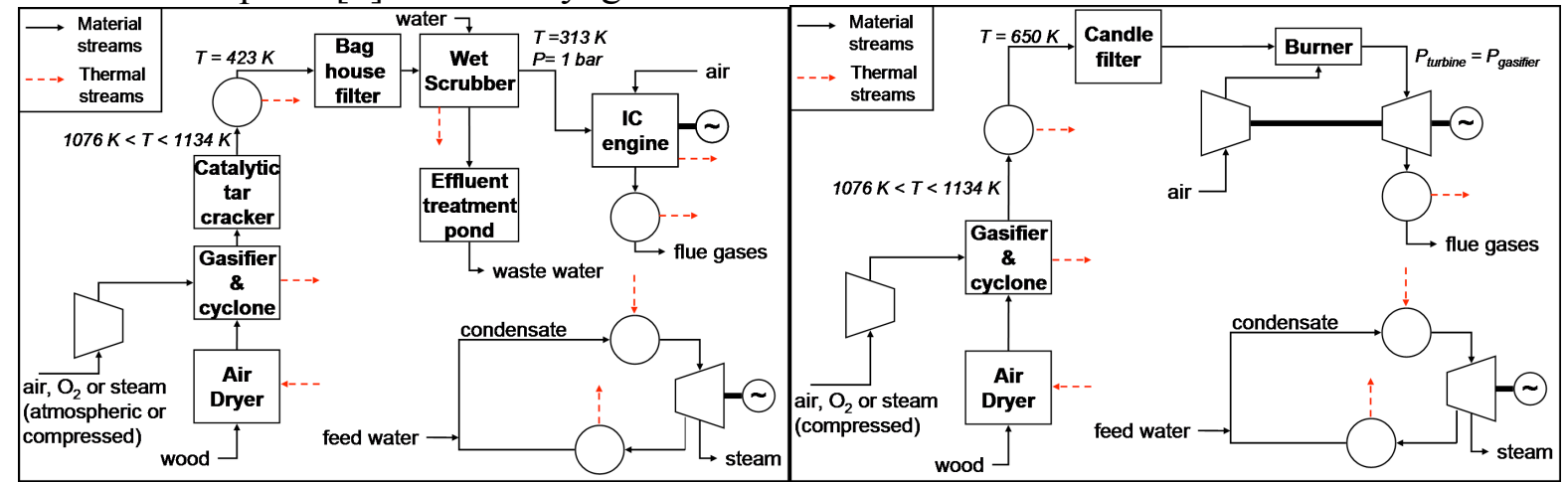

Fig. 1. ICE-CC energy flow diagram.

Fig. 2. GT-CC energy flow diagram.

separation, ITM is not, however, yet a mature technology. For the gas cleaning sections, temperature and pressure losses in the different equipments were considered in the flowsheet calculations, but the conversion and removal of contaminants was essentially not simulated except for the flash separation of tar and $\mathrm{NH}_{3}$ in the wet scrubbers. ICE flowsheet modelling equations were defined as follows,

- The stoichiometric combustion fuel to air ratio was assumed to be 1.6.

- Mechanical efficiency $\eta_{m e c}$, engine cooling water requirements $\eta_{\text {cool }}$, and flue gas temperature $\left(\eta_{f l u e}\right)$ were related to the electrical power generation by empirical efficiency calculations [57],

$\eta_{\text {mec }}=0.2419\left(w_{I C E}^{-}\right)^{0.0653}$

$\eta_{\text {cool }}=0.7875\left(w_{\text {ICE }}^{-}\right)^{-0.1682}$

$\eta_{\text {flue }}=0.1556\left(w_{\text {ICE }}^{-}\right)^{0.0513}$ 
For the gas turbine,

- A constant isentropic efficiency of $80 \%$ was assumed for the air compressor and of $90 \%$ for the expansion turbine.

- The burner air was assumed to be at the same pressure as the producer gas.

- The fuel to air ratio was adjusted to maintain a burner outlet temperature of $1373 \mathrm{~K}$.

The bottoming steam cycle of the energy-integration model comprises a back pressure and condensing turbine with isentropic efficiencies of $80 \%$ and $70 \%$ respectively. Three steam utilisation levels are specified for air and oxygen gasification, while a forth extraction header is added to satisfy steam gasifier requirements. The shaft efficiencies of the electricity generators $\eta_{\text {gen }}$ were calculated as [58],

$\eta_{\text {gen }}=0.015 \ln \left(w^{-}\right)+0.8687$ if $w^{-} \leq 845 \mathrm{kWe}$

$\eta_{\text {gen }}=0.0013 \ln \left(w^{-}\right)+0.9611$ if $w^{-}>845 \mathrm{kWe}$

\subsubsection{Decision variables}

There are ten optimisation decision variables, listed in Table 4., including the gasifier type, the topping cycle configurations and their operating conditions, and steam cycle operational variables, the wood moisture content after drying (m.c.) and the equivalence ratio (ER) for air or oxygen gasification, or the steam to biomass ratio (SBR) for steam gasification, respectively defined as,

$$
\begin{aligned}
& \text { m.c. }=\dot{m}_{\text {moisture }} /\left(\dot{m}_{\text {wood }}+\dot{m}_{\text {moisture }}\right) \\
& E R=\dot{m}_{\mathrm{O}_{2}} / \dot{m}_{\mathrm{O}_{2} \text { theo }} \\
& S B R=\left(\dot{m}_{\text {moisture }}+\dot{m}_{\text {steam }}\right) / \dot{m}_{\text {wood }}
\end{aligned}
$$

The variables of Eqs.(4-6) are mass flow rates. $\dot{m}_{\text {moisture }}$ is the mass of water in wood, $\dot{m}_{\mathrm{O}_{2}}$ the mass of inlet oxygen to the gasifier, $\dot{m}_{\mathrm{O}_{2} \text { theo }}$ the theoretical mass of oxygen for stoichiometric

\begin{tabular}{|c|c|c|c|c|c|c|c|}
\hline$\overline{D V}$ & Variable & Limits & Units & DV & Variable & Limits & Units \\
\hline 1 & Dried wood m.c. & {$[3.3-24.7]$} & $\%$ & 6 & Oxidant $^{\#}$ & $\{1 ; 2 ; 3\}$ & Integer \\
\hline 2 & ER or SBR & {$[0.245-0.613]$} & - & 7 & ICE-CC / GT-CC & $\{0 ; 1\}$ & Binary \\
\hline 3 & Gasifier pressure & {$[1.65-20.15]$} & Bar & 8 & Boiler pressure & {$[12-60]$} & bar \\
\hline 4 & Gasifier temperature & [1076-1134] & $\mathrm{K}$ & 9 & Steam reheat $\mathrm{T}$ & [573-753] & $\mathrm{K}$ \\
\hline 5 & Oxidant ${ }^{\#}$ inlet $\mathrm{T}$ & {$[673-753]$} & $\mathrm{K}$ & 10 & Bleeding level T* & {$[273-573]$} & $\mathrm{K}$ \\
\hline
\end{tabular}
combustion, and $\dot{m}_{\text {steam }}$ the mass of steam injected into the gasifier.

Table 4. Decision variables of the optimisation problem.

\subsubsection{Cost function scaling variables}

Table 5. presents a summary of equipment sizing variables which were used for calculating capital costs in Eq.(3), and corresponding references for cost calculations. Flowsheet calculation results were used for determining these sizing parameters. The identification numbers in Tables 3 and 4 show what decision variables can directly or indirectly affect different equipment costs. It can be seen that the steam cycle operating variables and the inlet temperature of oxidant gases only affect heat exchanger and Rankine cycle costs. For the drying and gasification section equipments, sizing variables were determined from intermediary sizing parameters [6;59]. For instance compression power and reactor and conveyor heights were calculated in function of respectively the oxidant and producer gas flow rates. 
Table 5. Summary of equipment cost scaling variables

\begin{tabular}{|c|c|c|c|c|c|c|c|}
\hline Equipment & Sizing variable(s) & Ref. & DV & Equipment & Sizing variable(s) & Ref. & DV \\
\hline Drying & & & & Wet Scrubber & $\dot{V}_{\text {gas }}$ & A & $1-4 ; 6-7$ \\
\hline Dryer & $\dot{V}$ drying air & A & 1 & Effluent pond & $w_{\text {topping cycle }}$ & $\mathrm{D}$ & $1-4 ; 6-7$ \\
\hline Fan & $\dot{V}$ drying air & $\mathrm{B}$ & 1 & Topping cycle & & & \\
\hline \multicolumn{4}{|c|}{ Gasification and char combustion } & IC-engine & $w_{\text {topping cycle }}$ & $\mathrm{E}$ & $1-4 ; 6-7$ \\
\hline Conveyor & $H$ & A & $1-4 ; 6-7$ & Gas turbine & $w_{\text {topping cycle }}$ & $\mathrm{B}$ & $1-4 ; 6-7$ \\
\hline Compressor & $w_{\text {compressor }}$ & $\mathrm{B}$ & $1-3 ; 6-7$ & \multicolumn{4}{|c|}{ Heat exchanger network \& HRSG } \\
\hline Reactors & $d, h, P_{\text {gas }}, T_{\text {gas }} d u t y$ & $\mathrm{~B}$ & $1-4 ; 6-7$ & Exchangers & Area, $n_{\text {streams }}$ & $\mathrm{F}$ & $1-10$ \\
\hline Gas cleaning & & & & Rankine cycle & & & \\
\hline Cyclone & $\dot{V}_{\text {gas }}$ & A & $1-4 ; 6-7$ & Steam turbine & $w_{\text {Rankine cycle }}$ & $\mathrm{B}$ & $1-10$ \\
\hline Particle filter & $\dot{V}_{\text {gas }}$ & $\mathrm{C}$ & $1-4 ; 6-7$ & Pump & $P_{\text {boiler, }}, m_{\text {steam }}$ & $\mathrm{B}$ & $1-10$ \\
\hline Tar cracker & $\dot{V}_{\text {gas }}$ & $\mathrm{C}$ & $1-4 ; 6-7$ & & & & \\
\hline Bag filter & $\dot{V}_{g a s}$ & A & $1-4 ; 6-7$ & Generators & $w_{\text {topping, }}, w_{\text {Rankine cycle }}$ & $\mathrm{B}$ & $1-10$ \\
\hline
\end{tabular}

Notes: References for scaling equations: A: Ulrich [60]; B: Turton et al. [53]; C: Hamelinck et al. [61]; D: DeMeo and Galdo [62]; E: Brammer and Bridgwater [63]; F: Chauvel [64]; Variables: $d$ : reactor diameter; $h$ : reactor height; $P$ : pressure, $T$ : temperature, $\dot{V}$ : inlet volumetric flow, $w$ : power; DV: decision variables of influence on scaling variable (see corresponding numbers in Table 4). HRSG: heat recuperation steam generator.

\section{Results and analysis}

\subsection{Impact of decision variables on optimisation results}

The Pareto trade-off curves for the three types of gasifiers are plotted in Fig. 3. After 15000 evaluations, steam gasification had the most favourable trade-off, and that of air gasification mostly dominated that of oxygen gasification. The correlation coefficients between the objectives and the decision variables are plotted in Fig 4. Most variables are similarly correlated (positively or negatively) in regard to both objectives. This confirms that total investment costs and electricity conversion exergy efficiency are indeed conflicting objectives, as can be also seen in Table 6, where detailed results for tail points are indicated. Variables are also often similarly correlated in regard to different gasification atmospheres. It is obvious from the lower part of Fig 3. (and also from Fig. 4), that the single variable that has the most important impact on the cost/efficiency trade-off is the binary variable coding for the choice of a topping cycle and gas cleaning strategy. Regardless of the oxidant,

- Electricity conversion efficiencies tend to be maximised with ICE-CC.

- Investment costs tend to be minimised with GT-CC.
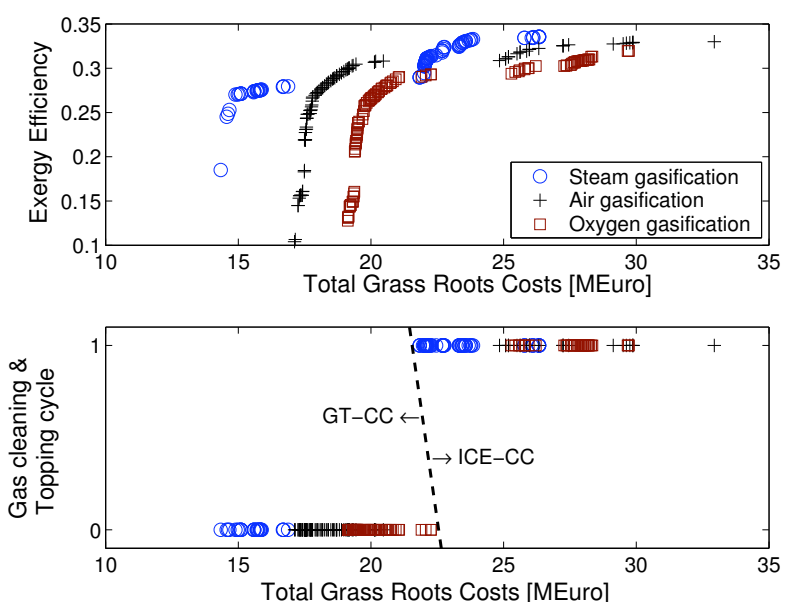

Fig. 3. Trade-off points (after 15000 evaluations).

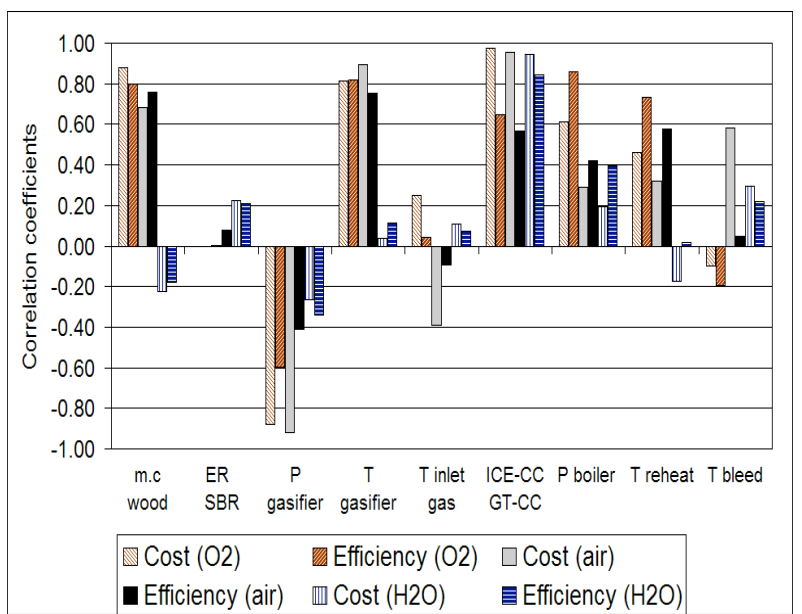

Fig. 4. Correlation coefficients of objectives and decision variables. 
Table 6. End points of trade-off curve for the $20 \mathrm{MW}_{\text {th }}$ installation

\begin{tabular}{|c|c|c|c|c|c|c|c|}
\hline \multicolumn{2}{|c|}{ Reactor (n. iterations) } & \multicolumn{2}{|c|}{$\begin{array}{c}\mathrm{O}_{2} \text { gasification } \\
(15000)\end{array}$} & \multicolumn{2}{|c|}{ Air gasification (15000) } & \multicolumn{2}{|c|}{$\mathrm{H}_{2} \mathrm{O}$ gasification (15000) } \\
\hline & Units & Max eff. & Min cost & Max eff. & Min cost & Max eff. & Min cost \\
\hline Invest. Costs & $\mathrm{k} €$ & 29717 & 19129 & 32939 & 17122 & 26335 & 14339 \\
\hline Exergy efficiency & - & 0.32 & 0.13 & 0.33 & 0.10 & 0.34 & 0.19 \\
\hline Electric eff. & - & 0.41 & 0.17 & 0.43 & 0.13 & 0.43 & 0.24 \\
\hline Power & $\mathrm{kWe}$ & 8269 & 3303 & 8534 & 2690 & 8685 & 4786 \\
\hline Specific cost & $\mathrm{k} € / \mathrm{kWe}$ & 3.59 & 5.79 & 3.86 & 6.37 & 3.03 & 3.00 \\
\hline Comp. curve & - & - & - & Fig. 5 left & Fig. 6 right & - & - \\
\hline m.c dried wood & - & 0.25 & 0.06 & 0.23 & 0.06 & 0.03 & 0.03 \\
\hline ER or SBR & - & 0.25 & 0.25 & 0.25 & 0.25 & 0.34 & 0.33 \\
\hline$P$ gasifier & bar & 6.40 & 16.50 & 2.5 & 8.65 & 3.7 & 11.85 \\
\hline T gasifier & $\mathrm{K}$ & 1123.5 & 1077.5 & 1134 & 1076 & 1119 & 1114 \\
\hline $\mathbf{T}$ inlet & $\mathrm{K}$ & 753 & 737 & 611 & 591.5 & 753 & 749.5 \\
\hline Top. Cycle & - & ICE & GT & ICE & GT & ICE & GT \\
\hline P boiler & bar & 37.95 & 15.05 & 36.55 & 60 & 58.05 & 13 \\
\hline$T$ reheat & $\mathrm{K}$ & 752.5 & 574 & 752.5 & 577 & 753 & 749.5 \\
\hline T bleed & $\mathrm{K}$ & 368 & 386.5 & 420 & 386 & 464.5 & 381.5 \\
\hline Tar & $\mathrm{mg} / \mathrm{Nm}^{3}$ & 5189 & 33891 & 15 & 382 & 5354 & 86034 \\
\hline $\mathbf{N}_{2}$ & $\%$ & 0.2 & 0.3 & 47.7 & 59.6 & 0.2 & 0.2 \\
\hline $\mathbf{H}_{2}$ & $\%$ & 11.5 & 13.3 & 10.7 & 7.5 & 20.1 & 14.2 \\
\hline $\mathrm{CO}_{2}$ & $\%$ & 49.3 & 59.5 & 18.9 & 21.2 & 31.2 & 38.2 \\
\hline $\mathrm{CO}$ & $\%$ & 14.6 & 9.8 & 13.8 & 5.8 & 16.8 & 9.4 \\
\hline $\mathrm{CH}_{4}$ & $\%$ & 11.5 & 10.4 & 6.1 & 4.4 & 17.3 & 17.1 \\
\hline Other HC & $\%$ & 12.8 & 5.6 & 2.7 & 1.0 & 14.3 & 18.3 \\
\hline $\mathbf{N H}_{3}$ & $\%$ & $5.44 \mathrm{E}-03$ & $3.18 \mathrm{E}-02$ & $5.91 \mathrm{E}-02$ & 4.63E-01 & $4.38 \mathrm{E}-02$ & $4.56 \mathrm{E}-02$ \\
\hline Furfural & $\%$ & $2.58 \mathrm{E}-02$ & 7.19E-01 & $8.41 \mathrm{E}-05$ & $6.52 \mathrm{E}-03$ & $6.46 \mathrm{E}-03$ & $9.03 \mathrm{E}-02$ \\
\hline Phenol & $\%$ & $1.21 \mathrm{E}-01$ & $3.99 \mathrm{E}-01$ & $2.41 \mathrm{E}-04$ & $1.55 \mathrm{E}-03$ & $1.40 \mathrm{E}-01$ & $1.81 \mathrm{E}+00$ \\
\hline Naphthalene & $\%$ & $1.28 \mathrm{E}-02$ & $1.62 \mathrm{E}-02$ & $1.69 \mathrm{E}-07$ & $2.14 \mathrm{E}-06$ & $1.34 \mathrm{E}-02$ & $6.80 \mathrm{E}-01$ \\
\hline Pyridine & $\%$ & $4.17 \mathrm{E}-03$ & $1.83 \mathrm{E}-02$ & $1.06 \mathrm{E}-04$ & $2.94 \mathrm{E}-03$ & $6.54 \mathrm{E}-03$ & $6.58 \mathrm{E}-02$ \\
\hline Char & $\%$ & 5 & 23 & 6 & 24 & 10 & 10 \\
\hline
\end{tabular}

Notes: the regression parameters of the reaction model provide from atmospheric air gasification data. Gas and tar species concentrations are expressed on a dry basis; char as a percentage of dry ash free wood, electric efficiency based on the LHV of 50\% m.c. wood. Reference year for costs is 2004 (actualised with Marshall \& Swift annual equipment cost indices).

The impact of the other variables on the cost-efficiency trade-off is less evident. Higher boiler pressures tend to maximise energy conversion efficiency (and increase investment costs), although for air gasification this effect does not appear to be significantly correlated to the objective functions. For air and oxygen gasification, there are similar trade-offs according to operating gasification temperature and pressure, the inlet feedstock moisture content, and the boiler reheat temperature; but for steam gasification these trade-offs do not exist (or are not obvious in the case of operating temperature and pressure). ER and SBR are not strongly correlated variables because they practically always take constant values. Lower oxidant to biomass ratios favouring appear to be preferable. In fact, because ER is almost consistently on its lower bound for all oxygen and air gasification trade-off points, this variable is probably strongly correlated to both objectives, but not conflictingly. The optimisation shows that the lower bound on ER should be reduced. This would allow to reach autothermal configurations, and contribute to further improve both objectives. Within the specified operating limits, autothermal operating conditions are approached only at high gasification temperatures. For steam gasification, the optimal SBR for both objectives appears to be within the specified limits. The variable steam bleed temperature and the inlet oxidant gas temperature appear to 
have little impact on the cost-efficiency trade-off, since they are neither significantly correlated to the objective functions, nor do they take constant values.

Four integrated composite curves for ICE-CC and GT-CC (for air gasification) are shown in Figs. $5 \& 6$. With the contribution of the heat of the flue gases from the turbine or the engine, the only pinch points created are those of the optimal energy conversion system (this is also the case for steam and oxygen gasifiers). For air and oxygen gasification, the energy conversion efficiency is maximised with autothermal gasification and when the dryer outlet moisture content of wood remains high (on its upper bound). With these oxidant gases, wood drying is not critical because moisture also contributes to gasifying the feedstock and increasing the heating value of the producer gas. Conversely, for steam gasification a low moisture content is favoured to increase the heating value of producer gas. When total investments are minimised (e.g. Fig 6 right, GT-CC, also in Table 6.) power production is minimal and process steam is inefficiently used for wood drying, thereby raising the specific capital cost above $6000 € / \mathrm{kW}$. Conversely, when the process efficiency is maximised specific capital costs are improved (e.g. Fig 5 left, ICE-CC, also in Table 6.). The ICE has a low temperature $\left(90^{\circ} \mathrm{C}\right)$ cooling requirement representing approximately $20 \%$ of the producer gases lower heating value. For optimal heat integration, the engine coolant could possibly be used for preheating wood drying air or boiler feed water.
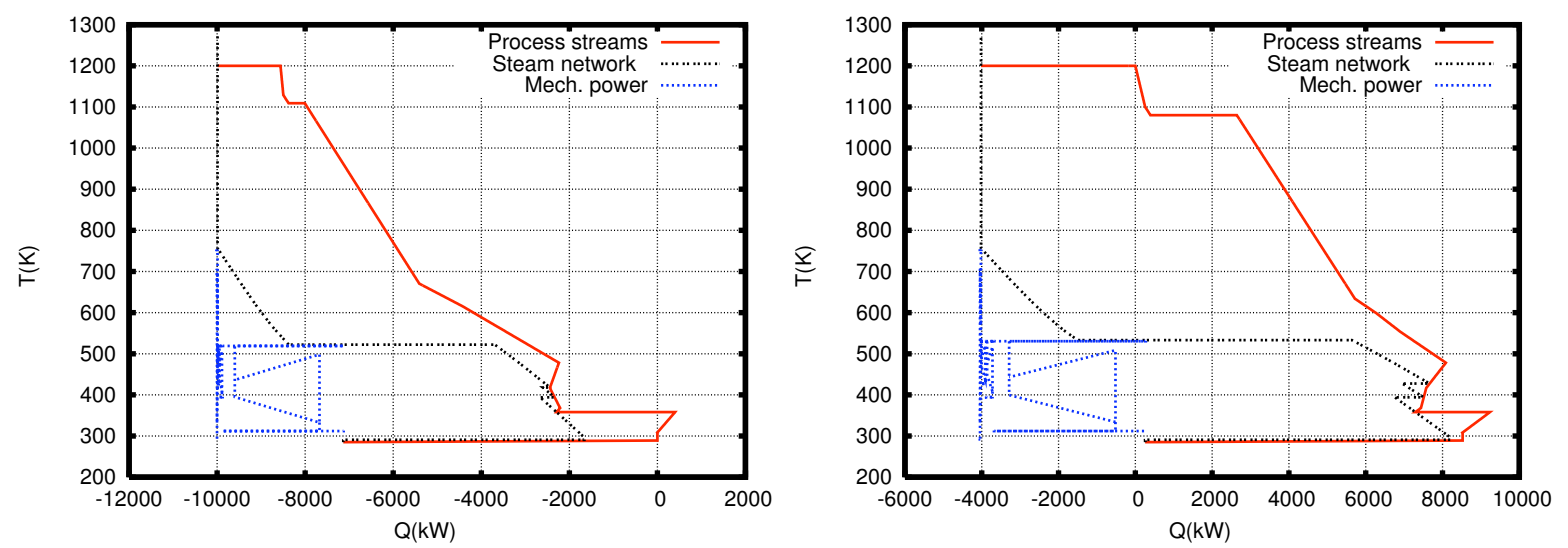

Fig. 5. Integrated composite curves for ICE-CC air gasification (left: max eff., right: min cost).
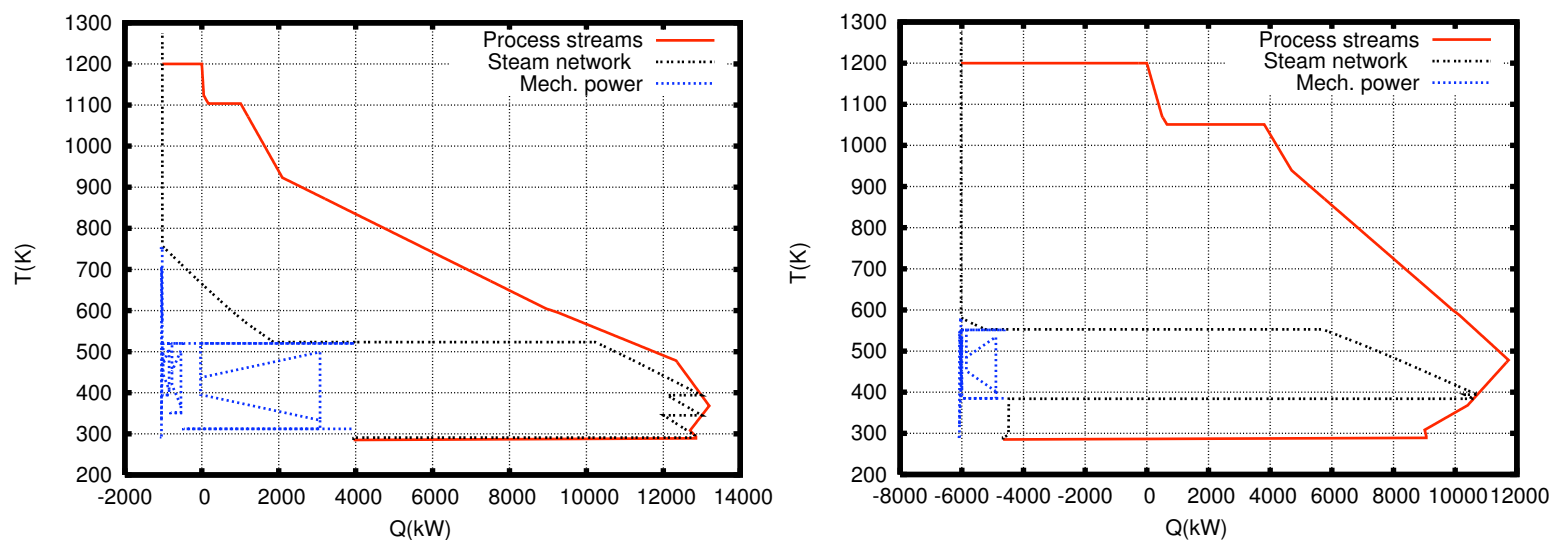

Fig. 6. Integrated composite curves for GT-CC air gasification (left: max eff., right: min cost).

\subsection{Evaluation of solutions in function of other performance criteria}

By re-plotting the Pareto trade-off points, other indicators can also serve as guidelines for evaluating and choosing among the different process configurations and operation conditions. Of particular interest are the specific capital investment costs. Since the daf mass flow rate and chemical exergy of wood are constant, they can be viewed as a measure of the trade-off 
between both objectives. It is also of interest to examine results in function of gasifier tar concentrations. In Fig. 7 the specific capital costs (upper left) and gasifier outlet tar concentrations (lower left), as well the gasification temperature (upper right) and pressure are separately plotted as a function of total grass roots costs. Recalling from Fig 3. that the split between GT-CC and ICE-CC solutions is located between 21 and $23 \mathrm{M} €$, it can be seen that GT-CC is superior to ICE-CC in terms of specific costs. Solutions that favour the lowest specific costs for GT-CC range from 15-21 M€. These configurations are also predicted to maximise tar formation (at low temperature and high pressure operating conditions). This should not be of concern with hot gas cleaning provided that tar does not condense before the producer gas is combusted in the burner. The conditions maximising ICE-CC efficiency with cold gas cleaning (low pressure and high temperatures) favour minimal tar formation, but specific capital costs are optimal when capital costs are in the interval of 22-26 M€ where tar concentrations remain high for air and oxygen gasification due to higher operating pressures. In respect to the different oxidants and in terms of optimal specific capital costs, steam gasification still appears as the best option (with specific costs of $2130 € / \mathrm{kWe}$ for GT-CC, and $2717 € / \mathrm{kWe}$ for ICE-CC) followed by air (GT-CC: $2465 € / \mathrm{kWe}$; ICE-CC: $3110 € / \mathrm{kWe}$ ) and oxygen gasification (GT-CC: $2805 € / \mathrm{kWe}$; ICE-CC: $3324 € / \mathrm{kWe}$ ).
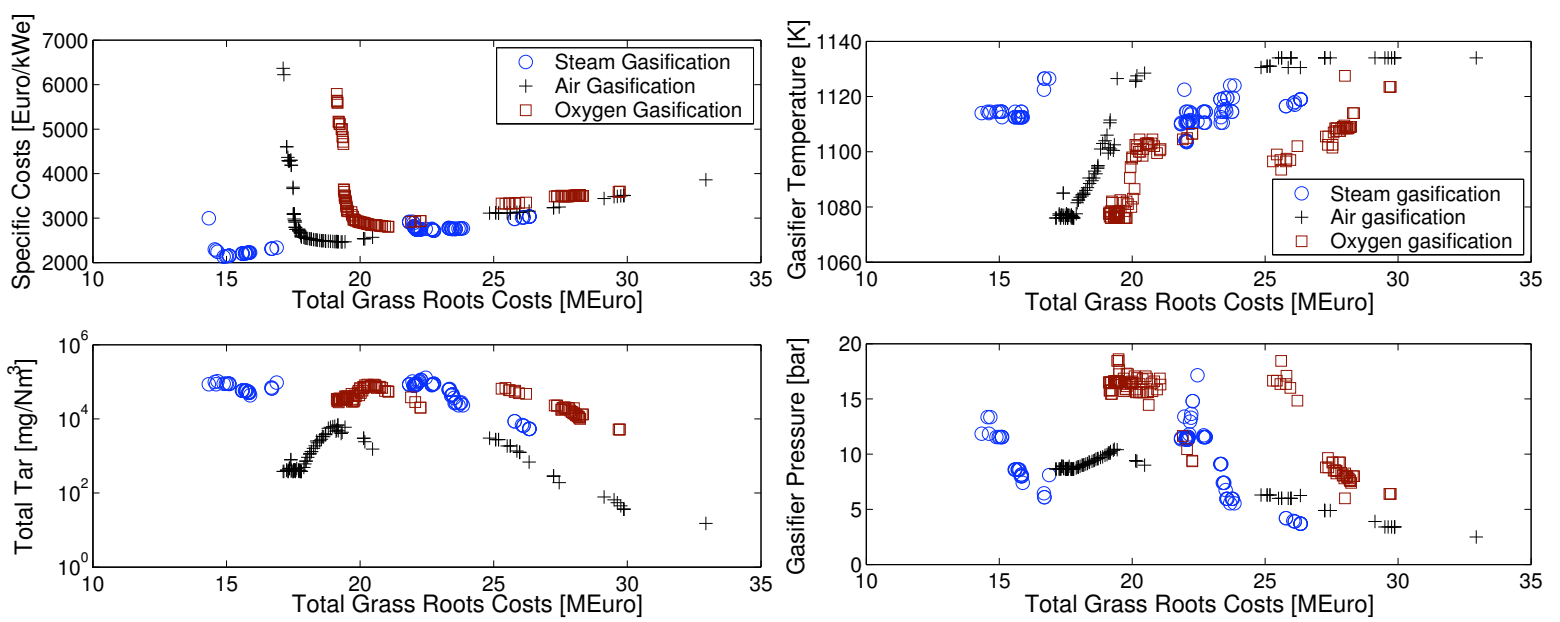

Fig. 7. Trade-off points characteristics as a function of total grass roots costs.

left: specific costs (upper) \& tar conc. (lower). right: temperature (upper) \& pressure (lower).

Table 7. Levelised electricity generation cost calculation parameters

\begin{tabular}{llllll}
\hline Lifetime & Availability & Wood $(50 \%$ hum $)$ & Labour costs & Maintenance & Interest rate \\
\hline 15 years & $90 \%$ & $16.5 € / \mathrm{kWh}_{\text {th }}$ & $240 \mathrm{k} € /$ year & $5 \% /$ year of $\mathrm{C}_{\mathrm{GR}}$ & $6 \%$ \\
\hline
\end{tabular}

Another possible evaluation criterion is the levelised cost of electricity generation. It is calculated as the average ratio of annual capital investments (with depreciation), operations, maintenance, and fuel expenditures to the electricity generation over the lifetime of the project [65]. Calculation parameters are indicated in Table 7. As indicated in Fig. 8, (left for optimal specific capital costs and right for all trade-off points), the economic advantage of GT-CC over ICE-CC is less apparent in terms of electricity generation costs than in terms of specific capital costs, because GT-CC solutions are penalised by higher relative fuel and operator costs due to their lower efficiency. Maintenance and depreciation costs are proportional to specific capital costs, hence do not contribute to changing the order of solutions. It can be noted from Fig. 8 (left) that the breakeven point between GT-CC (109.9 $€ / \mathrm{kWhe})$ and ICE-CC (110.5 €/kWhe) is almost reached for the steam gasification scenario. Also the gap between the levelised costs for different oxidants is relatively smaller than for specific costs. Optimal air gasification GT-CC (109€/MWhe) electricity generation costs are 
slightly better than for steam gasification. The optimal electricity generation costs solutions are identical to the optimal capital costs solutions except for air gasification GT-CC (109.4 $€ /$ MWhe generation costs for optimal specific capital costs of $2465 € / \mathrm{kWe}$ ).
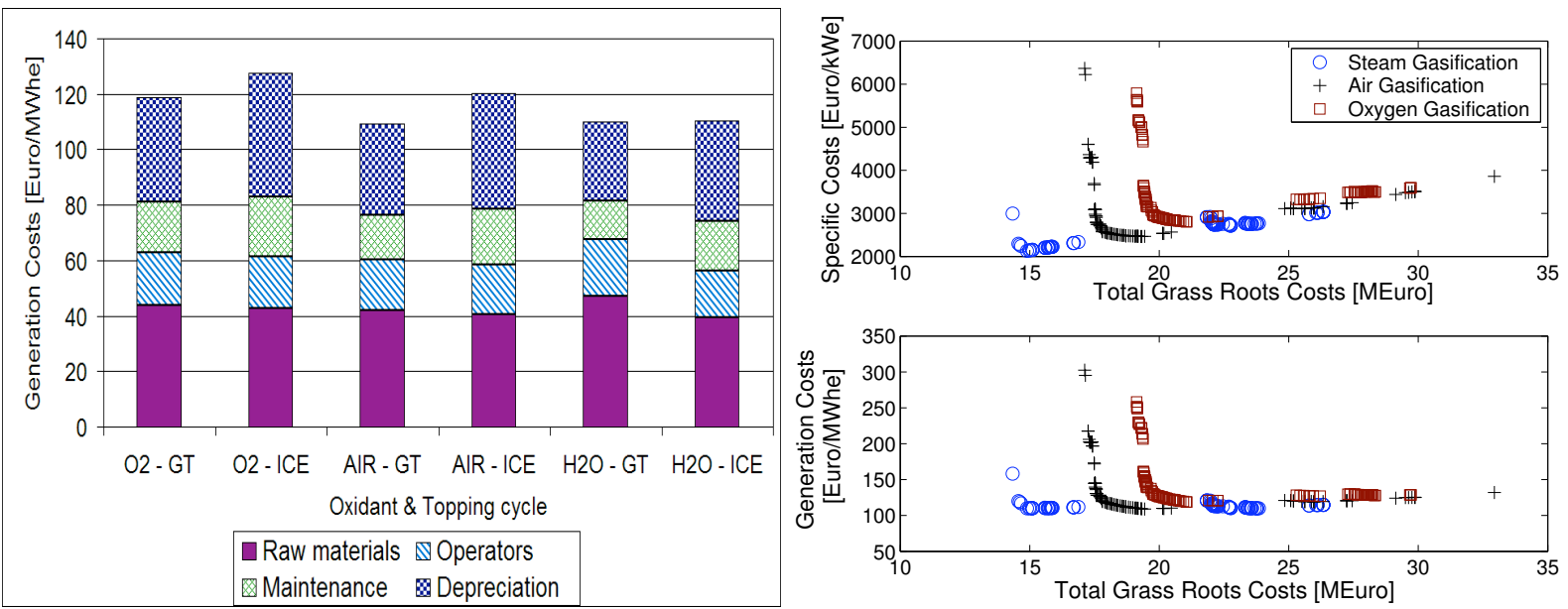

Fig. 8. Levelised electricity generation costs for optimal specific capital costs (left); and specific capital costs (upper right) and levelised electricity generation costs (lower right) vs. total grass root costs.

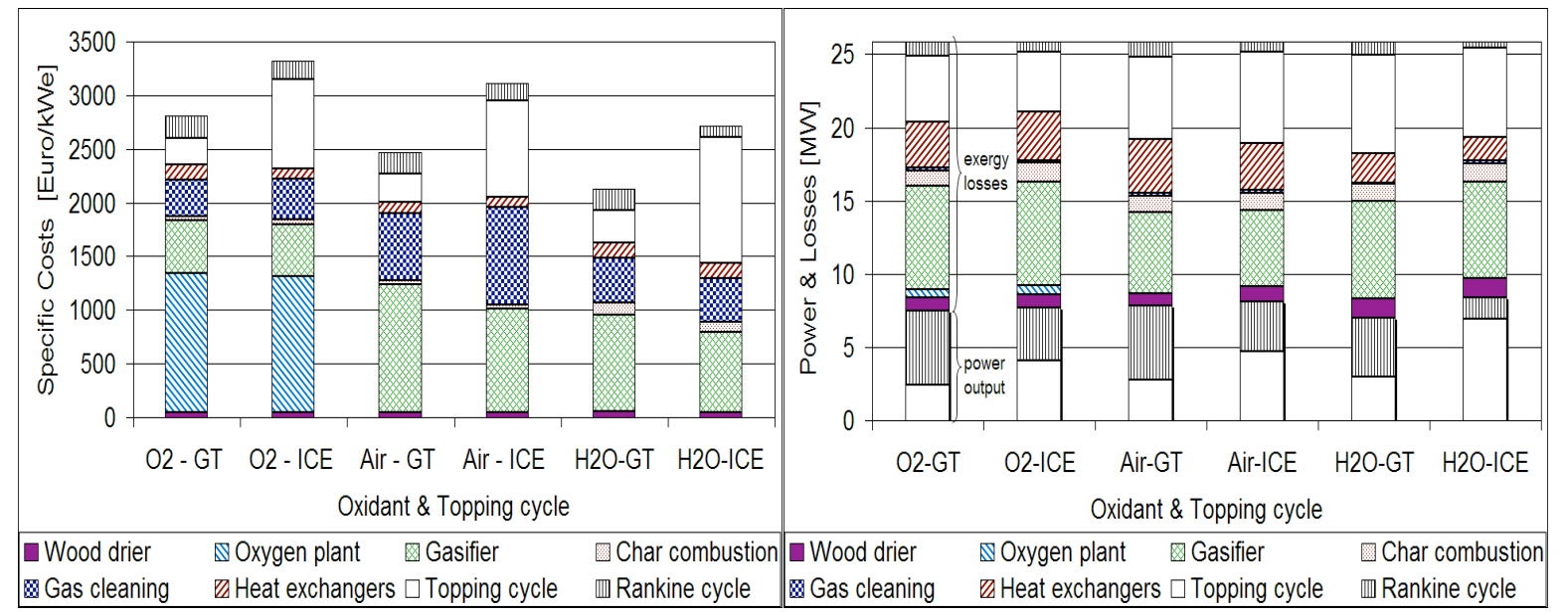

Fig. 9. Optimal specific costs (left: specific costs per processing step; right: power generation and exergy losses).

The breakdown of optimal specific capital costs for ICE-CC and GT-CC per processing step is indicated in Fig. 9 (left). The cost of wood dryers and heat exchangers is small compared with other equipments. Average HEN costs vary in function of heat exchanger surface, and are slightly higher for indirect steam gasification. Oxygen plant, gasifier, and gas cleaning equipment costs vary essentially in function of the volumetric flow of gases. As a consequence, oxygen gasification, although penalised by the incremental cost of the ASU, is advantaged by the lower cost of the gasifier and gas cleaning equipment, which become higher for air gasification due to nitrogen gas and also for steam gasification due to the higher oxidant to biomass ratio. Recalling from Fig. 7 (right) that paradoxically air gasification and low pressure conditions are predicted by equilibrium calculations to minimise tar concentrations, improving gas cleaning equipment cost estimation functions by linking them to contaminant mass flow rates would be of interest. Gas turbine, ICE, and steam turbine costs are mainly a function of their electrical power output. As steam gasification producer gas has a higher calorific value, gas turbine and ICE unit costs are higher than for air or oxygen 
gasification. However, as indicated on Fig 9. (right -the lower areas indicating electrical power generation), as a consequence of diverting steam to supply the indirectly heated gasifier, the relative contribution of the bottoming cycle to electricity production is less important for steam gasification than for air or oxygen gasification. In addition although the ICE is costlier than the gas turbine, is also more efficient. Regardless of the oxidant gas, the electricity production from the topping cycle is maximised with ICE-CC (53 to $83 \%$ of electricity production), and minimised with GT-CC (32-42\%).

Table 8. Exergy efficiency (in \%) of the conversion steps.

\begin{tabular}{lllllll}
\hline Section & $\mathrm{O}_{2}-\mathrm{GT}$ & $\mathrm{O}_{2}$-ICE & Air-GT & Air-ICE & $\mathrm{H}_{2} \mathrm{O}-\mathrm{GT}$ & $\mathrm{H}_{2} \mathrm{O}-\mathrm{ICE}$ \\
\hline Wood drier & 22.6 & 22.6 & 22.6 & 23.4 & 26.7 & 26.7 \\
Oxygen plant & 60.5 & 60.5 & & & & 76.4 \\
Gasifier & 73.0 & 72.7 & 79.2 & 80.4 & 76.4 & 76.8 \\
Char combustion & 69.7 & 69.7 & 69.7 & 69.7 & 68.8 & 67.7 \\
Gas cleaning & 88.9 & 92.4 & 92.1 & 91.2 & 93.3 & 85.9 \\
Topping cycle & 64.7 & 62.6 & 60.9 & 54.9 & 60.6 & 62.7 \\
Heat exchangers & 72.9 & 66.7 & 66.5 & 62.5 & 82.3 & 81.5 \\
Rankine cycle & 84.5 & 83.9 & 84.5 & 84.4 & 84.4 & 86.4 \\
\hline
\end{tabular}

Exergy balances for the separate processing steps have also been determined. The losses $\dot{L}$ and efficiencies $\eta$ of each conversion step are calculated as follows,

$\dot{L}=\sum \dot{E}_{c}^{+}+\sum \dot{E}_{q}^{+}+\sum \dot{E}_{w}^{+}-\left(\sum \dot{E}_{c}^{-}+\sum \dot{E}_{q}^{-}+\sum \dot{E}_{w}^{-}\right)$

$\eta=1-\frac{\dot{L}}{\sum \dot{E}_{c}^{+}+\sum \dot{E}_{q}^{+}+\sum \dot{E}_{w}^{+}}$

$\dot{E}_{c}^{+}$corresponds to the chemical exergy relating to material stream compositions, $\dot{E}_{q}^{+}$and $\dot{E}_{w}^{+}$ are respectively the thermal and mechanical stream exergies. The superscripts ' + ' and '-' correspond to inlet and outlet streams respectively. The chemical exergy of the inlet stream in the denominator of Eq.(9b) is included only when material stream compositions are changed by chemical reactions (i.e. combustion or gasification). Figure 9 (right -above the electricity output) shows the breakdown of the exergy losses for the same optimal specific cost solutions. The most important exergy losses are due to chemical reactions i.e., gasification and char combustion, and producer gas combustion in the topping cycle. Water evaporation with high temperature flue gases also induces considerable exergy losses in the steam generator of the heat exchanger section. The exergy efficiencies of the processing steps are indicated in Table 8 . The efficiency of wood drying is particularly low due to the loss of latent exergy in the exiting humid air. This represents 5 to $8 \%$ of the total exergy losses. A possible improvement to the process would be to use exiting humid air for inlet drying air preheating purposes. In regard to heat exchanger network losses, indirectly heated steam gasification appears more advantageous than heat recovery from exothermal air or oxygen gasification. As previously mentioned, lowering the bound on ER would allow wider operating windows for autothermal gasification, thereby reducing heat exchange losses, and also capital investments by decreasing the volume of gases.

\subsection{Validity and limits of stoichiometric equilibrium modelling}

In the optimisation problem formulation, the bounds on ER, moisture content, temperature, and the elemental composition of fuel were fixed according to the bounds of the data set used to obtain the temperature parameter regression. The air gasification product concentrations are generally within the limits reported by van der Drift et al. [50] for gas phase and tar specie concentrations. The char conversion ratio is in good agreement with the 
ratios (3 to 15\%) originally reported in van der Drift et al. [50], albeit somewhat high at lower temperatures. Discrepancies appear to be mostly due to the inaccuracies of mass balances, and perhaps the limited size of the data set. Therefore, the parametric stoichiometric equilibrium model appears to be a valid approach for data reconciliation purposes.

Having used atmospheric fluidised bed reaction data, the underlying assumption is that pressure does not affect temperature difference parameters. All other variables remaining equal, equilibrium modelling predicts that tar concentration increases, and char concentration decreases with increasing pressure. Qualitatively, this would seem to be confirmed by results presented by de Jong et al. [66] for the pressurised fluidised bed gasification of wood. However as show in Fig. 7., pressure has a considerable influence on estimated tar concentrations, and further investigation is essential to verify whether temperature difference parameters can actually be considered independent of pressure.

As shown in Table 6. and in Fig 7., model predictions of hydrocarbon and tar concentrations are also significantly higher for oxygen and steam gasification than for air gasification. However, the influence of the concentration of inert gas species on tar formation is seldom discussed in experimental studies, and it should not be surmised that air gasification necessarily improves tar conversion. Additional data is essential to clarify the true dependence of product distributions to gasification atmosphere composition.

From the perspective of equilibrium analysis, the variations induced by reaction pressure or by the partial pressures of oxidants and inert gases are similarly related to the stoichiometry of gas phase reactions [67]. Taking the stoichiometric coefficients of reactants to be negative and those of products to be positive, the extent of a reaction of which the sum of the coefficients is positive increases with increasing inert species concentrations (or decreases when the sum is negative). Likewise, the extent of a reaction of which the sum of the coefficients is positive decreases with increasing operating pressures (or increases when the sum is negative). Referring to Eq.(1), this explains why tar and hydrocarbon yields are predicted to increase, in high pressure conditions, and in absence of nitrogen.

The water gas shift reaction $\left(\mathrm{H}_{2} \mathrm{O}+\mathrm{CO} \leftrightarrow \mathrm{H}_{2}+\mathrm{CO}_{2}\right)$ is the only gas phase reaction of which the extent at equilibrium is predicted not to be modified by inert species concentrations or pressure, since the sum of its stoichiometric coefficients is equal to zero. In fact, the water gas shift temperature difference is probably also independent of gasification temperature and fuel composition, and on average appears to be close to equilibrium [5;13]. Because this reaction relates to the four major species of producer gas (excluding nitrogen), a constant temperature difference would provide another important justification for utilising equilibrium calculations.

\section{$\underline{\text { Conclusion }}$}

The thermo economic assessment of a biomass gasification energy conversion and gas cleaning process has been investigated with the multi-objective optimisation of a flowsheet superstructure. The use of atmospheric or pressurised air, oxygen or steam fluidised bed gasifiers, closed coupled to an internal combustion engine combined cycle (ICE-CC) and a cold gas cleaning system, or gas turbine combined cycle (GT-CC) and a hot gas cleaning have been considered. The trade-off between total investment costs and the exergy efficiency of electricity production for a plant capacity of $20 \mathrm{MW}_{\text {th,wood }}$ was obtained and analysed to identify process operating conditions that minimise tar formation.

Gas, tar, and char concentrations were estimated by the use of a stoichiometric equilibrium model comprising temperature difference parameter regressions. This modelling approach is simple enough for flowsheet optimisation calculations under changing operating conditions. For atmospheric fluidised bed air gasification, simulation results are in good 
agreement with the original experimental data. Assuming that the temperature difference parameters are independent of pressure, equilibrium modelling indicates that tar concentration will increase and char concentration decrease with increasing pressure. However, this assumption remains to be verified against relevant experimental data. Similarly, under steam and oxygen atmospheres equilibrium predicts an unlikely increase of tar and hydrocarbon concentrations. Therefore, further calibration would also be required to account for the impact of nitrogen gas concentrations in the reaction atmosphere.

Under the current modelling assumptions, optimisation results indicate that the energy conversion efficiency is maximised using ICE-CC at operating conditions that also favour low tar concentrations. Specific capital costs and electricity generation costs are optimal with GT$\mathrm{CC}$, albeit at conditions that could favour tar formation. However, this should not be of concern if tar condensation can effectively be prevented by maintaining high temperatures for hot gas cleaning. As for choosing among different oxidants, steam gasification would appear to have the best specific capital costs (the optimal specific cost of GT-CC is $2.1 € / \mathrm{We}$, while that of ICE-CC is $2.7 € / \mathrm{We}$ ), followed by air gasification (GT-CC: $2.5 € / \mathrm{We}$; ICE-CC: 3.1 $€ / \mathrm{We}$ ), and finally oxygen gasification (GT-CC: $2.8 € / \mathrm{We}$; ICE-CC: $3.3 € / \mathrm{We}$ ). In terms of annualised electricity generation costs, conversion efficiency contributes to narrowing the differences between the oxidants. Air gasification would be optimal for GT-CC (with 109.0 $€ /$ MWhe for GT-CC and $120.2 €$ /MWhe and for ICE-CC) steam gasification for ICE-CC (109.9 €/MWhe for GT-CC and 110.5 €/MWhe for ICE-CC), and still followed by oxygen gasification (118.7 and 127.4€/MWhe).

\section{Abbreviations}

$\begin{array}{ll}\text { ASU } & \text { air separation unit } \\ a r & \text { as received } \\ d a f & \text { dry ash free } \\ \text { ER } & \text { equivalence ratio (air or oxygen) } \\ \text { ITM } & \text { ion transfer membrane } \\ \text { GT-CC } & \text { gas turbine combined cycle } \\ \text { ICE-CC } & \text { internal combustion engine combined cycle } \\ \text { IGCC } & \text { integrated gasification combined cycle } \\ \text { m.c } & \text { moisture content } \\ \text { SBR } & \text { steam to biomass ratio }\end{array}$

\section{Acknowledgements}

David Brown gratefully acknowledges funding provided by the Ministry of Education, Culture, Sports, Science and Technology of Japan (Monbukagakusho), and the kind assistance of M. Raffaele Bolliger with the superstructure optimisation link code (Osmose).

\section{$\underline{\text { References }}$}

1. Quaak P., H. Knoef, and H.E. Stassen, Energy from Biomass: A Review of Combustion and Gasification Technologies, World Bank Publications, 1999, $100 \mathrm{p}$.

2. International Energy Agency, Renewables for power generation: status and prospects, 2003.

3. Babu S.P., IEA Bioenergy Agreement Task 33: Thermal Gasification of Biomass, Work Shop No. 1: Perspectives on Biomass Gasification, 2006.

4. Williams R.H. and E.D. Larson, Biomass Gasifier Gas Turbine Power Generating Technology, Biomass \& Bioenergy 10(2-3), 1996, 149-66. 
5. Duret, A., C. Friedli and F. Maréchal, Process design of Synthetic Natural Gas (SNG) production using wood gasification, Journal of Cleaner Production., 13-15, 2005, 1434-46.

6. Gassner M. and F. Marechal, Thermo-economic optimisation of the integration of electrolysis in a wood to methane process, Proc. ECOS 2006, 19th International Conference on Efficiency, Cost, Optimization, Simulation and Environmental Impact of Energy Systems, 2, 2006, 553-61.

7. Milne T.A., R.J. Evans and N. Abatzoglou, Biomass Gasifier "Tars": Their Nature, Formation, and Conversion, NREL, US DoE, Report no. NREL/TP-570-25357, 1998.

8. van de Kamp W.L., P.J. de Wild, J.H.A. Kiel, U. Zielke, M. Suomalainen, H. Knoef, J. Good, T. Liliedahl, C. Unger, M. Whitehouse, J. Neeft, H.W. van de Hoek, Tar measurement standard for sampling and analysis of tars and particles in biomass gasification product gas, $14^{\text {th }}$ European Biomass Conference and Exhibition, Paris, France 2005.

9. Godat J. and F. Maréchal, Optimization of a fuel cell system using process integration techniques, Journal of Power Sources, 118(1-2), 411-23.

10. Maréchal F., F. Palazzi, J. Godat, D. Favrat, Thermo-economic modelling and optimisation of fuel cell systems, Fuel Cells 5(1), 2004, 5-24.

11. Bolliger R., D. Favrat, and F. Marechal., Advanced power plant design methodology using process integration and multi-objective thermo-economic optimisation., proc. ECOS 2005, 18th International Conference on Efficiency, Cost, Optimization, Simulation and Environmental Impact of Energy Systems, 2, 2005, 777-84.

12. Maréchal F., B. Kalitventzeff, Process integration: Selection of the optimal utility system, Computers and Chemical Engineering, 22, 1998, 149-56.

13. Brown, D., T. Fuchino and F. Maréchal, Solid Fuel Decomposition Modelling for the Design of Biomass Gasification Systems, Proc. ESCAPE-16/PSE9, CAPE-21B, eds. W. Marquardt and C. Pantelides, 1661-6, 2006.

14. Stevens D.J., Hot Gas Conditioning: Recent progress with larger-scale biomass gasification systems update and summary of recent progress, NREL, US DoE, Report no. NREL/SR-510-29952, 2001.

15. Devi L., K.J. Ptasinski, F.J.J.G. Janssen, A review of the primary measures for tar elimination in biomass gasification processes, Biomass \& Bioenergy, 24, 2003, 125 40.

16. Evans R.J. and Milne T.A., Molecular characterization of the pyrolysis of biomass. 1. fundamentals, Energy \& Fuels, 1, (2), 1987, 123-37.

17. Morf P., P. Haslerb and T. Nussbaumer, Mechanisms and kinetics of homogeneous secondary reactions of tar from continuous pyrolysis of wood chips, Fuel, 81(7), 2002, 843-53.

18. Hasler P., Th. Nussbaumer, Gas cleaning for IC engine applications from fixed bed biomass gasification, Biomass \& Bioenergy, 16, 1999, 385-95.

19. Pan Y.G., X. Roca, E. Velo and L. Puigjaner, Removal of tar by secondary air in fluidised bed gasification of residual biomass and coal, Fuel, 78, 1999, 1703-9.

20. Zhang R., R.C. Brown, A. Suby, K. Cummer, Catalytic destruction of tar in biomass derived producer gas, Energy Conversion and Management 45, 2004, 995-1014.

21. Gil J., M.A. Caballero, J.A. Martin, M.P. Aznar and J. Corella, Biomass gasification with air in fluidized bed: effect of in-bed use of dolomite under different operation conditions, Industrial and Engineering Chemistry Research, 38, 1999, 4226-35.

22. Bridgwater A.V., D.C. Elliott, L. Fagerniis, J.S. Gifford, K.L. Mackie, and A.J. Toft, The nature and control of solid, liquid and gaseous emissions from the thermochemical processing of biomass, Biomass \& Bioenergy, 9, 1995, 325-41. 
23. Bergman P.C.A., S.V.B. van Paasen, and H. Boerrigter, The novel "OLGA" technology for complete tar removal from biomass producer gas, Pyrolysis and Gasification of Biomass and Waste Expert Meeting, 2002, Strasbourg, France.

24. Peukert W. and C. Wadenpohl, Industrial separation of fine particles with difficult dust properties, Powder Technology 1182001 136-48.

25. Simell P., E. Kurkela, P. Stahlberg, J. Hepola, Catalytic hot gas cleaning of gasification gas, Catalysis Today, 27, 1996, 55-62.

26. Ma L., H. Verelst and G.V. Baron, Integrated high temperature gas cleaning: Tar removal in biomass gasification with a catalytic filter, Catalysis Today 105, 2005, 729-34.

27. Devi L., M. Craje, P. Thüne, K. J. Ptasinski and F.J.J.G. Janssen, Olivine as tar removal catalyst for biomass gasifiers: Catalyst characterization, Applied Catalysis A: General, 294, 2005, 68-79.

28. Walawender W.P., D.A. Hoveland, and L.T Fan. Steam gasification of alpha cellulose in a fluid bed reactor. In: Overend RP, Milne TA, Mudge LK, editors. Fundamentals of thermochemical biomass conversion. London: Elsevier Applied Science, 1985. p. $897-910$.

29. Corella J, Aznar MP, Gil J, Caballero MA., Biomass gasification in fluidised bed: where to locate the dolomite to improve gasification?, Energy \& Fuels 1999, 13, $1122-$ 7.

30. Engelen K., Y. Zhang, D. J. Draelants, G. V. Baron, A novel catalytic filter for tar removal from biomass gasification gas: Improvement of the catalytic activity in presence of $\mathrm{H}_{2} \mathrm{~S}$, Chemical Engineering Science 58, 2003, 665-70.

31. Glarborg P., A.D. Jensen, J.E. Johnsson, Fuel nitrogen conversion in solid fuel fired systems, Progress in Energy and Combustion Science 29, 2003, 89-113.

32. EPA Technical Bulletin, Nitrogen Oxides (NOx), Why and How they are Controlled, EPA 452/F-99-006R, Chapel Hill, North Carolina, 1999.

33. Boerrigter H., H. Bodenstaff, R.W.A Wilberink, J.Kuipers, M.Geusebroek, Pyrolysis of biomass and coal in a bubbling fluidised-bed reactor, fate of fuel bound nitrogen, ECN report C-04_08, 2004.

34. Stahl K., M. Neergaard, J. Nieminen, Progress Report: Varnamo Biomass Gasification Plant, Gasification Technologies Conference, San-Francisco, USA, 1999.

35. Baxter L.L., T.R. Miles, T.R. Miles, Jr., B.M. Jenkins, D. Dayton, T. Milne, R.W. Bryers, L.L. Oden, The behavior of inorganic material in biomass-fired power boilersfield and laboratory experiences, Vol. II, Alkali deposits found in biomass power plants, NREL, 1996.

36. Aho M., E. Ferrer, Importance of coal ash composition in protecting the boiler against chlorine deposition during combustion of chlorine-rich biomass, Fuel, 84, 2005, 20112.

37. Aho M., J. Silvennoinen, Preventing chlorine deposition on heat transfer surfaces with aluminium-silicon rich biomass residue and additive, Fuel 83, 2004, 1299-1305.

38. Turn S.Q., C.M. Kinoshita, D.M. Ishimura, T.T. Hiraki, J. Zhou, and S.M. Masutani, An Experimental Investigation of Alkali Removal from Biomass Producer Gas using a Fixed Bed of Solid Sorbent, Proc. Fourth Biomass Conference of the Americas, R.P. Overend and E. Chornet, eds. Elsevier Science, Oxford, UK, 1999, 934-46.

39. Turn S.Q., C.M. Kinoshita and D.M. Ishimura, Removal of inorganic constituents of biomass feedstocks by mechanical dewatering and leaching, Biomass \& Bioenergy, 12, (4), 1997, 241-52. 
40. Brown D., F. Maréchal and J. Paris, A dual representation for targeting process retrofit, application to a pulp and paper process, Applied Thermal Engineering, 25(7), 2005, 1067-82.

41. Larson E. D., S. Consonni, and T. G. Kreutz, Preliminary Economics of Black Liquor Gasifier/Gas Turbine Cogeneration at Pulp and Paper Mills, Journal of Engineering for Gas Turbines and Power 122, 2000, 255-61.

42. Bridgwater A.V. The technical and economic feasibility of biomass gasification for power generation, Fuel, 14(5), 1995, 631-53.

43. Waldheim L. and E. Carpentieri, Update on the Progress of the Brazilian Wood BIGGT Demonstration Project, Journal of Engineering for Gas Turbines and Power123(3), 2001, 525-36

44. Brun K. and R.M. Jones, Economic Viability and Experience of IGCC From a Gas Turbine Manufacturers Perspective, ASME - IGCC Turbo Expo, (2001)

45. Hofbauer H., R. Rauch, G. Löffler, S. Kaiser, E. Fercher, H. Tremmel, Six years experience with the FICFB-gasification process, in: 12th European conference and technology exhibition on biomass for energy, industry and climate protection, Amsterdam, 2002.

46. Pitcher K., B. Hilton and H. Lundberg, The ARBRE Project: Progress Achieved, Biomass and Bioenergy, 15(3), 1998, 213-8

47. Bini R., A. Duvia, A. Schwarz, M. Gaia, P. Bertuzzi, W. Righini, Operational results on the first CHP plant in Italy based on a organic Rankine Cycle Turbogenerator and overview of a number of plants in operation in Europe since 1998, $2^{\text {nd }}$ World conference on Biomass, Rome, 2004.

48. Bridgwater A.V., Renewable fuels and chemicals by thermal processing of biomass., Chemical Engineering Journal, 91, 2003, 87-102.

49. Sridhar G., P.J. Paul and H.S. Mukunda, Biomass derived producer gas as a reciprocating engine fuel — an experimental analysis, Biomass \& Bioenergy, 21, 2001, 61-72.

50. van der Drift A., J. van Doorn and J.W. Vermeulen, Ten residual biomass fuels for circulating fluidized-bed gasification, Biomass \& Bioenergy, 20, 2001, 45-56.

51. Belsim s.a., VALI 4 User Guide (2005), http://www.belsim.com.

52. Szargut J. and T. Styrylska, Angenäherte Bestimmung der Exergie von Brennstoffen, BWK 16(12), 1964, 589-96.

53. Turton R., R.C. Bailie, W.B. Whiting and J.A Shaeiwitz, Analysis, synthesis, and design of chemical processes, Prentice Hall, New Jersey, 1998.

54. Leyland. G, 2002. "Multi-objective optimisation applied to industrial energy problems", Doctoral thesis, Ecole Polytechnique Fédérale de Lausanne, Switzerland.

55. Golberg, D.E., 1989, Genetic Algorithms in Search Optimization and Machine Learning, Addison-Wesley, Reading, MA, United-States.

56. Rauch R., H. Hofbauer, K. Bosch, I. Siefert, C. Aichernig, H. Tremmel, K. Voigtlaender, R. - Koch, R. Lehner, Steam gasification of biomass at CHP plant Guessing - status of the demonstration plant, in: 2nd World Conference and Technology Exhibition on Biomass for Energy, Industry and Climate Protection, Rome, 2004.

57. van Stein E. E., E. Juwono, E. P. Demetri, The impact of ITM oxygen on economics for coal-based IGCC, in: 27 th International technical conference on coal utilization \& fuel systems, Clearwater, 2002.

58. Marechal F., Kalitventzeff B., "Computer-Aided Integration of Utility Systems", in Computer Aided Process \& Product Engineering, Eds. L. Puigjaner \& G. Heyen, Wiley-VCH, Weinheim, 2006. 
59. Gassner M., 2005. "Energy integration and thermo-economic evaluation of a process converting wood to methane", Master's thesis, Ecole Polytechnique Fédérale de Lausanne, Switzerland.

60. Ulrich, G.-D., A guide to chemical engineering process design and economics, Wiley, New York, 1984.

61. Hamelinck C. N., A.P.C. Faaij, H. den Uil, H. Boerrigter, Production of FT transportation fuels from biomass; technical options, process analysis and optimisation, and development potential, Energy, 29, 2004, 1743-71

62. DeMeo E.A., J.F. Galdo, Renewable Energy Technology Characterizations, TR109496 Topical Report, December 1997, Office of Utility Technologies, Energy Efficiency and Renewable Energy, U.S. DOE and EPRI

63. Brammer J.G., A.V. Bridgwater, The influence of feedstock drying on the performance and economics of a biomass gasifier engine CHP system, Biomass \& Bioenergy, 22, 2002, 271-81.

64. Chauvel, A., Fournier, G., Raimbault, C., Manuel d'évaluation économique des procédés, Technip, Paris, 2001.

65. IEA / OECD, Projected costs of generating electricity, 2005.

66. de Jong W., Ö. Ünal, J. Andries, K. R. G. Hein and H. Spliethoff, Thermochemical conversion of brown coal and biomass in a pressurised fluidised bed gasifier with hot gas filtration using ceramic channel filters: measurements and gasifier modelling, Applied Energy, 74(3-4), 2003, 425-37.

67. Smith W.R. and R. Missen, (1982). Chemical Reaction Equilibrium Analysis: Theory and Algorithms., (Ch. 8 p. 173-200), USA.: John Wiley and Sons, 364p. 